Weed Technology

www.cambridge.org/wet

\section{Intriguing World of Weeds}

Cite this article: Sosnoskie LM, Hayes RM, Steckel LE (2020) Hophornbeam copperleaf (Acalypha ostryifolia Riddell). Weed Technol. 34: 305-307. doi: 10.1017/wet.2019.126

Received: 4 September 2019

Revised: 18 November 2019

Accepted: 21 November 2019

First published online: 30 January 2020

\section{Author for correspondence:}

Lawrence E. Steckel, University of Tennessee, 605 Airways Blvd. Jackson, TN 38301.

Email: Isteckel@utk.edu

Associate Editor Name \& Institution:

Bradley Hanson, University of California, Davis

\title{
Hophornbeam copperleaf (Acalypha ostryifolia Riddell)
}

\section{Lynn M. Sosnoskie ${ }^{1}$, Robert M. Hayes ${ }^{2}$ and Lawrence E. Steckel ${ }^{2}$ []}

${ }^{1}$ Assistant Professor, Cornell University, Geneva, NY, USA and ${ }^{2}$ Professor, University of Tennessee, Jackson, TN, USA

Get someone else to blow your horn and the sound will carry twice as far. Will Rogers

\author{
It is said that love makes the world go 'round - the announcement lacks verification. \\ It's wind from the dinner horn that does it. \\ O. Henry
}

The finest workers in stone are not copper or steel tools, but the gentle touches of air and water working at their leisure with a liberal allowance of time.

Henry David Thoreau

\section{Introduction}

Hophornbeam copperleaf (Acalypha ostryifolia Riddell) is an erect, herbaceous, dicot species in the Euphorbiaceae, or spurge, family that constitutes more than 200 genera and some 6,000 species (Mayfield and Webster 2013). Although the euphorbs have a cosmopolitan distribution, none are found in the Arctic (Mabberley 1997). Members of the Euphorbiaceae may be trees, shrubs, herbs (occasionally aquatic), or vines; sometimes succulent and cactus-like; and often have glands on vegetative plant parts (Mabberley 1997; Zomlefer 1994). Genera in the spurge family include Croton, Euphorbia, Ricinus, and Acalypha. Acalypha consists of 450 species that are native to both the Eastern and Western hemispheres (Zomlefer 1994). Acalypha was the name used by Hippocrates because the leaves resemble those of nettles, whereas ostryifolia alludes to the resemblance of leaves to plants in the genus Ostrya (hophornbeam trees; Burrows and Tyrl 2013; Haddock 2014; Hilty 2018). As plants mature in the fall, the leaves can turn reddish-brown, which may indicate why "copperleaf" is included in the species' common name (Hilty 2018). Hophornbeam copperleaf is native to North America; it occurs in the United States ranging from Arizona east to Florida, north to Pennsylvania, and west to Nebraska (Anonymous 2019). It occurs in a variety of habitats including agronomic fields, cultivated areas, landscapes, roadsides, river and stream banks, thickets, pastures, and waste sites (Bryson and DeFelice 2010; Haddock 2014; Hilty 2018). This plant's other common names include copperleaf, pineland three-seed mercury, Virginia copperleaf, hornbeam mercury, hornbeam three-seed mercury, mercury, and rough-pod copperleaf (Bryson and DeFelice 2010; Haddock 2014; Hilty 2018; Steckel 2006).

\section{Description}

Hophornbeam copperleaf seedlings have two round cotyledons, similar to those of the mallow family. The cotyledons and seedling stems of hophornbeam copperleaf are pubescent, while the first leaves are sparsely hairy. The first true leaves are oppositely arranged. The mature stems are erect, $0.3-0.8 \mathrm{~m}$ tall, simple to usually branched, and are pubescent. The trichomes are sparse to dense, glandular, or short and recurved. Although many members of the spurge family produce a milky sap, hophornbeam copperleaf lacks this characteristic. Leaves of mature plants are alternate, $3.0-10.0 \mathrm{~cm}$ long, $1.5-5.0 \mathrm{~cm}$ wide, simple, ovate to rhombic-ovate with sharply serrated margins, and are sparsely pubescent. Petioles are typically $2.0-7.0 \mathrm{~cm}$ long and stipules are typically $1.5 \mathrm{~mm}$ long. Inflorescences are both terminal and axillary. Female spikes are terminal, $3.0-11.0 \mathrm{~cm}$ long, with deeply cleft subtending bracts. Male florets occur on axillary spikes, are $1.0-3.0 \mathrm{~cm}$ long, crowded, with subtending bracts that are $2.0-7.0 \mathrm{~mm}$ long and $5.0-12.0 \mathrm{~mm}$ wide. Fruits occur in a 2.0- to 3.5 - $\mathrm{mm}$-long, pubescent capsule that has tuberculate projections and are three-seeded (hence the alternate common name: three-seed mercury). Seeds are ovoid, 1.4-2.3 mm long, silvery gray in color, and tuberculate (Bryson and DeFelice 2010). Reproduction is solely by seed. The mature plant has fibrous roots originating from a taproot.

Hophornbeam copperleaf seedlings are often mistaken for Sida spinosa (prickly sida or teaweed; Bradley and Rosenbaum 2011). Seedling prickly sida plants have one round and one heart-shaped cotyledon, which is a trait that can be used to distinguish between it and 


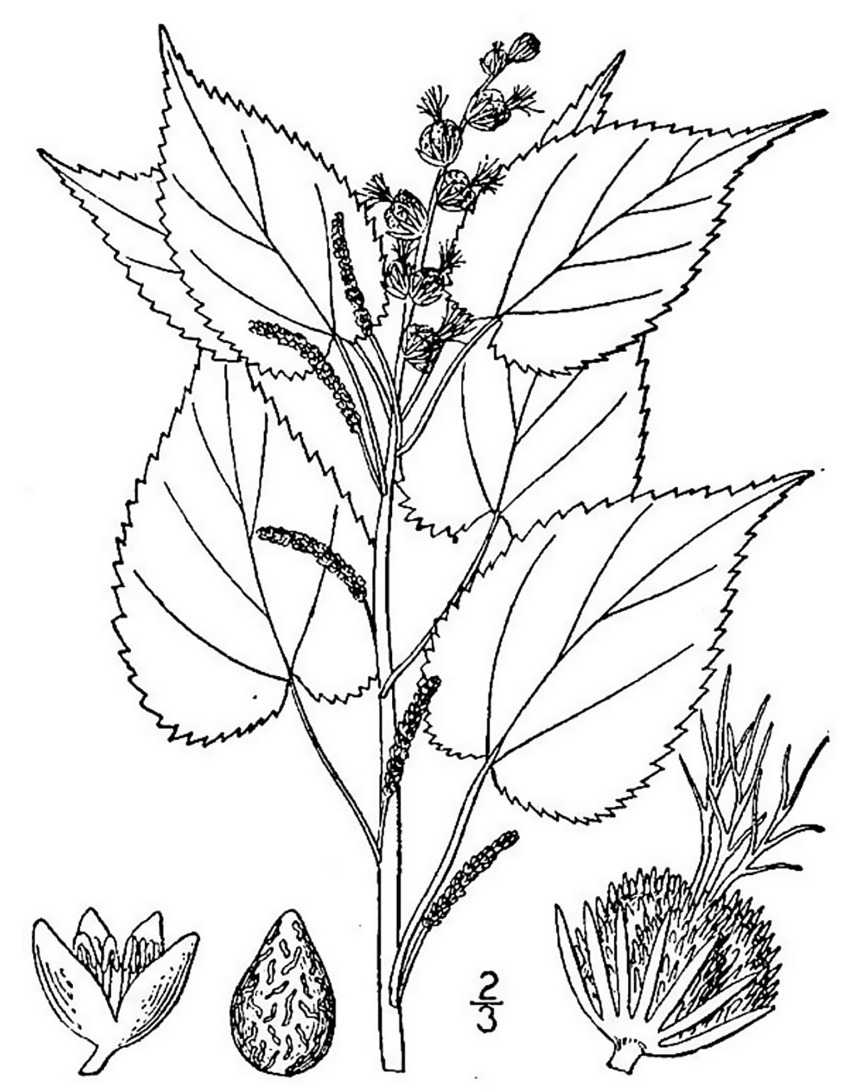

Drawing reproduced from Britton and Brown (1913)

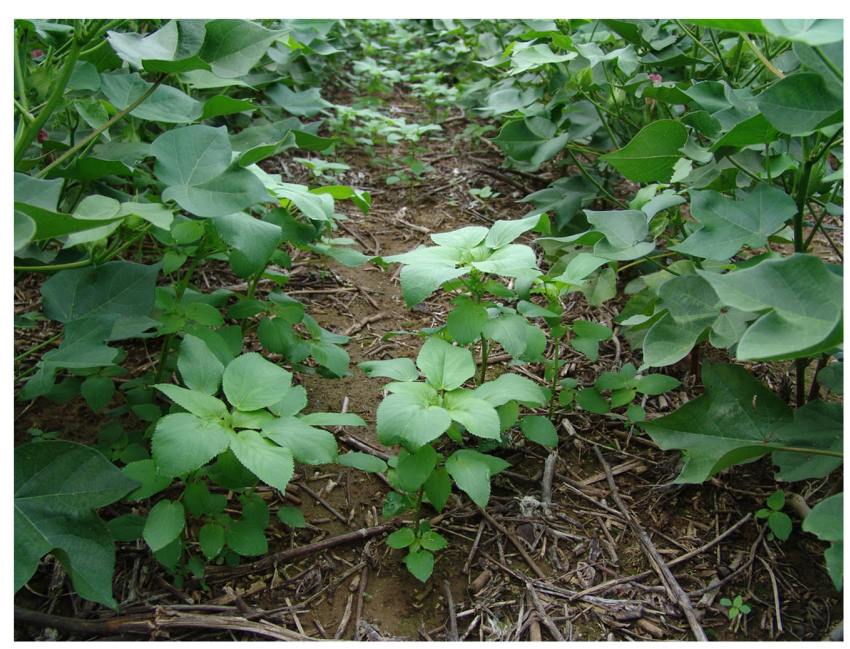

Hopehornbeam copperleaf competing with cotton

hophornbeam copperleaf s round cotyledons. The first true leaves of hophornbeam copperleaf are opposite compared with the alternate true leaves of prickly sida. Additionally, the leaf margins of prickly sida are more coarsely serrated than the sharply serrated leaves of hophornbeam copperleaf. Copperleaf also lacks the small stipules (spines) in leaf axils that prickly sida has (Bradley and Rosenbaum 2011). A related species, Virginia copperleaf (A. virginica L.) can be a troublesome weed species as well.

\section{Weediness}

Hophornbeam copperleaf prefers full or partial sun, moist to mesic conditions, and can thrive in both disturbed and undisturbed areas. Hophornbeam copperleaf plants are capable of producing numerous seeds. Horak et al. (1998) conducted a study examining its biology and control among soybean (Glycine max L. Merr.) plantings and found that hophornbeam copperleaf grown alone produced 12,510 seeds per plant, whereas plants grown in competition with soybean produced 980 seeds per plant. Hophornbeam copperleaf fruit capsules are dehiscent (capsules split open at maturity to release seed), which aids dispersal. Although this plant reseeds itself, animals may also contribute to propagule movement (Hilty 2018; Miller and Miller 1999). Plants may be found singly or in large colonies.

Although scarification is not required for seed germination, cold stratification for up to $3 \mathrm{wk}$ increased germination compared to no cold stratification time (Horak et al. 1998). Whereas hophornbeam copperleaf seeds can germinate over a wide range of temperatures, which could explain how these plants can thrive in varying environments, Horak et al. (1998) found that alternating temperatures of $30 \mathrm{C}$ to $20 \mathrm{C}$ were optimal for germination. These results are consistent with observations that emergence can begin in late spring or early summer and continue throughout the growing season (Driver and Oliver 1984). Steckel (2006) reported that hophornbeam copperleaf can be found across many fields in mid to late summer in the mid-South region of the United States. Hophornbeam's ability to germinate in warmer temperatures throughout the summer allows it to emerge after most herbicide applications (Steckel 2006). With respect to soil $\mathrm{pH}$, hophornbeam copperleaf seed can germinate at levels between 5.1 and 10.9, with an optimum $\mathrm{pH}$ for germination of 7.0.

Hophornbeam copperleaf has been reported to be a weedy pest of corn (Zea mays L.), soybean, peanut (Arachis hypogaea L.), and watermelon (Citrullus lanatus L.; Baldwin et al. 1974; Brandenberger et al. 2005; Horak et al. 1998; Prostko 2017; Stephenson et al. 2015). For example, Prostko (2017) reported that hophornbeam copperleaf can occur at densities that have the potential to reduce yields and influence harvest efficiency in peanuts grown in Georgia (Prostko 2017). Conversely, Steckel (2006) noted that hophornbeam emerges later in the soybean growing season and is less likely to reduce yields. However, hophornbeam copperleaf plants that emerge after crop maturity could flower and add seed to the soil seed bank, thereby impacting crops in following years. Hophornbeam copperleaf has also been reported to be an early invader of sites prepared for forest plantations (Miller and Miller 1999).

No-till row crop production along with glyphosate-tolerant crops has likely provided an environment for this weed to thrive (Steckel 2006). The reduction in the use of cultivation and applications of soil-applied residual herbicides and the species' tolerance to glyphosate has allowed this weed to become more widespread in the mid-South and midwestern United States (Horak et al. 1998; Steckel 2006). The species also has some tolerance to acetolactate synthase-inhibiting herbicides often used POST in cotton (Gossypium hirsutum L.), corn, and soybeans (Steckel 2006). Despite these limitations, the application of both PRE and POST herbicides has been recommended for the management of extremely dense populations of hophornbeam copperleaf (Prostko 2017). In more recent years with the widespread adoption of soybean and cotton that is tolerant to POST dicamba applications 
(Wechsler et al. 2019) in the mid-southern United States, there has been an increase in the frequency of reports from growers of hophornbeam copperleaf infesting those crops (authors' personal observations). This is not surprising because dicamba is not that effective on hophornbeam copperleaf (Steckel 2019).

\section{Toxicity}

Consumption of plants may cause digestive irritation, colic, and diarrhea, although to a lesser extent than the related species, Virginia copperleaf, A. virginica (Bryson and DeFelice 2010; Burrows and Tyrl 2013). The problem is a result of the presence of diterpene esters, which cause irritation to the mucosa of the digestive tract (Burrows and Tyrl 2013). Another poisonous plant in the Acalypha family is the chenille plant, A. hispida Burm.f. (Zomlefer 1994). However, a related species, slender copperleaf (A. gracilens Gray), is a highly used forage plant by white-tailed deer (Odocoileus virginianus) throughout the southeastern U.S. in the summer (Miller and Miller 1999). Additionally, it has been reported that the Cherokee people used the roots of Virginia copperleaf as a drug to treat urinary problems (Moerman 1998).

\section{Other Uses}

Unlike most Euphorbs, hophornbeam copperleaf flowers are pollinated by wind (anemophilous), and therefore, they don't attract many pollinators. The species is, however, an early season wild host plant for two important crop insect pests, corn earworm (Helicoverpa zea Boddie) and tobacco budworm (Heliothis virescens F.), in Tennessee (Sudbrink and Grant 1995). Interestingly, a research study found that sweet corn patches infested with hophornbeam copperleaf had higher densities of predacious lady beetle (Coleomegilla maculata DeGeer) larvae and increased predation on corn earworm eggs compared with patches that lacked these weeds (Cottrell and Yeargen 1998). This was perhaps due to a preference by the lady beetle to lay eggs on plants with abundant glandular trichomes when available. Additionally, eggs oviposited on these plants suffered less cannibalism and predation than those on plants without these anatomical structures.

Interestingly enough, although Acalphya have some toxic properties, both copperleaf species and chenille plant are considered ornamentals (Zomlefer 1994). That hophornbeam copperleaf could be a fellow traveler with man by being an ornamental to some while at the same time becoming more of a troubling weed to others shows it has evolved to fit in well to its currently diverse environments. Hophornbeam copperleaf is quite a long-winded name for such a short-statured plant, and it is indeed proving to be a pesky weed problem where it becomes established.

\section{References}

Anonymous (2019) USDA Plants. https://plants.usda.gov/core/profile? symbol=ACOS. Accessed: September 2, 2019

Baldwin F, Santelmann P, Greer H (1974) Weed control systems for hophornbeam copperleaf control in peanuts. Agron J 66:789-792
Bradley K, Rosenbaum K (2011) Weed of the month: Hophornbeam copperleaf. https://ipm.missouri.edu/IPCM/2011/7/Weed-of-the-MonthHophornbeam-Copperleaf/index.cfm. Accessed: January 29, 2019

Brandenberger LP, Shrefler JW, Webber CL, Talbert RE, Payton ME, Wells LK, McClelland M (2005) Preemergence weed control in direct-seeded watermelon. Weed Technol 19:706-713

Britton NL, Brown A (1913) An illustrated flora of the northern United States, Canada and the British possessions. 3. Vols. New York: Charles Scribner's Sons. Vol 2, p 457

Bryson CT, DeFelice MS (2010) Weeds of the midwestern United States and central Canada. Athens, GA: University of Georgia Press. $427 \mathrm{p}$

Burrows GE, Tyrl RJ (2013) Toxic plants of North America. 2nd ed. Ames, IA: John Wiley \& Sons, Inc. 1,308 p

Cottrell TE, Yeargen KV (1998) Influence of a native weed, Acalypha ostryifolia (Euphorbiceae), on Coleomegilla maculata (Coleoptera: Coccinellidae) population density, cannibalism in sweet corn. Environ Entomol 27:1375-1385

Driver TL, Oliver LR (1984) Control of hophornbeam copperleaf (Acalypha ostraefolia) in soybeans and peanuts. Arkansas Farm Res 33:6

Haddock M (2014) Kansas wildflowers and grasses. http://www.kswildflower. org_details.php?flowerID=584. Accessed: January 20, 2019

Hilty J (2018) Illinois wildflowers. https://www.illinoiswildflowers.info/prairie/ plantx/cm_primrosex.htm. Accessed: January 22, 2019

Horak MJ, Gao ZP, Peterson DE, Maddux LD (1998) Hophornbeam copperleaf (Acalypha ostryifolia) biology and control. Weed Technol 12:515-521

Mabberley DJ (1997) The plant-book. New York: Cambridge University Press. $859 \mathrm{p}$

Mayfield MH, Webster GL, eds (2013) Euphorbiaceae, in Jepson Flora Project. Jepson eFlora, Revision 1. http://ucjeps.berkeley.edu/eflora/eflora_display. php?tid=133. Accessed: August 30, 2019

Miller JH, Miller KV (1999) Forest plants of the southeast and their wildlife uses. Westminster, CO: Southern Weed Science Society of America. $134 \mathrm{p}$

Moerman DE (1998) Native American ethnobotany. Portland, OR: Timber Press Inc. $927 \mathrm{p}$

Prostko EP (2017) Hophornbeam copperleaf identification and control in peanut. Circular 882. Athens, GA: University of Georgia. http://extension. uga.edu/publications/detail.html?number $=\mathrm{C} 882 \&$ title $=$ Hophornbeam $\%$ 20Copperleaf\%20Identification\%20and\%20Control\%20in\%20Peanut. Accessed January 25, 2019

Steckel L (2019) Weed control manual for Tennessee. Knoxville: University of Tennessee. Extension publication PB 1580.http://www.utcrops.com/weeds/ PDfs/PB1580.pdf. Accessed: November 15, 2015. p 47

Steckel L (2006) Hophornbeam copperleaf. Knoxville: University of Tennessee Extension publication W120

Stephenson D, Bond J, Landry R, Edwards H (2015) Weed management in corn with postemergence applications of tembotrione or thiencarbozone. Weed Technol 29:350-358

Sudbrink DL, Grant JF (1995) Wild hosts of Helicoverpa zea and Heliothis virescens (Lepidoptera, Noctuidae) in eastern Tennessee. Environ Entomol 24:1080-1085

Wechsler SJ, Smith D, McFadden J, Dodson L, Williamson S (2019) The use of genetically engineered dicamba-tolerant soybean seeds has increased quickly, benefiting adopter's but damaging crops and some fields. Washington, DC: US Department of Agriculture-Economic Research Service. https://www.ers.usda. gov/amber-waves/2019/october/the-use-of-genetically-engineered-dicambatolerant-soybean-seeds-has-increased-quickly-benefiting-adopters-butdamaging-crops-in-some-fields/. Accessed: September 15, 2019

Zomlefer WB (1994) Guide to flowering plant families. Chapel Hill: University of North Carolina Press. $430 \mathrm{p}$ 